\title{
Inheritance of Phytophthora Stem Blight Resistance as Compared to Phytophthora Root Rot and Phytophthora Foliar Blight Resistance in Capsicum annuum L.
}

\author{
Ousmane Sy' ${ }^{1}$ and Paul W. Bosland ${ }^{2}$ \\ Department of Agronomy and Horticulture, New Mexico State University, Las Cruces, NM 88003 \\ Robert Steiner ${ }^{3}$ \\ University Statistics Center, New Mexico State University, Las Cruces, NM 88003
}

\begin{abstract}
ADDITIONAL INDEX WORDS. chile pepper, disease syndrome, oomycete, gene-for-gene, Phytophthora capsici
AbSTRaCt. The pathogen Phytophthora capsici Leon. is known to be a limiting factor of chile pepper (Capsicum L.) production around the world. The genetics of the resistance is becoming better understood due to the specific nature of the host-pathogen interaction, i.e., all plant organs are subject to infection. It has been shown that phytophthora root rot resistance and phytophthora foliar blight resistance are under different genetic mechanisms. This study aimed at understanding the inheritance of resistance of phytophthora stem blight and to determine whether phytophthora stem blight was the same disease syndrome as phytophthora root rot and phytophthora foliar blight. Stem cuttings of a segregating $\mathrm{F}_{2}$ population and testcross progeny facilitated the ability to screen for two disease syndromes concurrently. When the three disease syndromes were compared separately, the $F_{2}$ populations fit a 3 resistant (R) : 1 susceptible (S) ratio and the testcross progenies fit a $1 \mathrm{R}: 1 \mathrm{~S}$ ratio. When comparative studies were performed (stem vs. foliar and stem vs. root), the $F_{2}$ populations fit a $9 R / R: 3 R / S: 3 S / R: 1 S / S$ ratio and the testcross fit a $1 R / R: 1 R / S: 1 S / R: 1 S / S$ ratio. These ratios are consistent of a single gene controlling the resistance of each system. Therefore, phytophthora stem blight, root rot, and foliar blight are three separate disease syndromes.
\end{abstract}

Phytophthora [(Ant). de Bary] species are oomycetes, which morphologically and physiologically resemble fungi, but are phylogenetically distant from them (Brett, 2002). The pathogen Phytophthora capsici Leon. is a limiting factor of chile pepper production around the world. This pathogen is capable of causing several disease syndromes in chile: phytophthora root rot, fruit rot, foliar blight, and possible stem blight (Alcantara and Bosland, 1994; Bartual et al., 1991; Biles et al., 1993; Kim et al., 1989; Reifschneider et al., 1992). Several investigations have been carried out to understand the inheritance of resistance of chile pepper to $P$. capsici, but contradicting results have been reported (Ortega et al., 1991; Reifschneider et al., 1992; Smith et al., 1967). The multiple disease syndromes caused by $P$. capsici complicates the situation. Therefore, a comprehensive inheritance study could assist in developing a durable and complete resistance against the pathogen. Walker and Bosland (1999) reported that two different resistance genes were necessary for root rot and for foliar blight resistance. However, phytophthora stem blight has not been investigated extensively.

The development of reliable screening techniques using different plant organs could provide a better way to investigate the inheritance of more than one disease resistance simultaneously. However, in such case, the plant could be weakened after being

Received for publication 12 July 2004. Accepted for publication 11 Aug. 2004. A contribution of the New Mexico Agr. Expt. Sta., New Mexico State Univ., Las Cruces.

${ }^{1}$ Graduate Research Assistant.

${ }^{2}$ Regents Professor. To whom reprint requests should be addressed. E-mail: pbosland@nmsu.edu

${ }^{3}$ Associate Professor. tested for the first disease and the results obtained for the second would therefore be biased. An alternative method is to make stem cuttings (clones) that will provide genetically identical plants that can be tested separately for two diseases. Such a study using clonal propagation proved that this method was acceptable (Sy, 2003).

The objectives of this study were to 1) investigate the inheritance of phytophthora stem blight, root rot, and foliar blight resistance and 2) determine whether stem blight was a different disease syndrome or part of the root rot or the foliar blight syndromes.

\section{Materials and Methods}

Plant materials. The plant populations consisted of a segregating $\mathrm{F}_{2}$ population obtained from an hybridization between a susceptible variety, 'Early Jalapeño', and a resistant line, Criollo de Morelos 334. Those two parents also served as controls. In addition, a testcross population was developed by backcrossing the $\mathrm{F}_{1}$ progeny to the susceptible parent, 'Early Jalapeño'. Sixweek-old seedlings were grown in planting trays composed of 96 cells or eight 12-celled containers (Hummert International, Earth City, Mo.). Cells were filled with a commercially prepared peat moss-vermiculite soil mixture (Metromix 360; Scotts-Sierra Horticultural Products Co., Marysville, Ohio). Two to three seeds were planted in each cell and later thinned to one plant per cell. The trays were then placed on heated propagation pads to help promote germination in the greenhouse. After $\approx 4$ weeks, stem cuttings were made of all lines.

Stem cuttings were made from the controls, the testcross, and the segregating $\mathrm{F}_{2}$ population. Plants were cut above the cotyledons. A cross was sliced into the bottom of each cutting, which 
was then dipped in growth hormone (Rhizopon AA \#1; Hortus USA Corp., New York) to promote rooting of the cuttings.

INOCULUM PREPARATION. An isolate of $P$. capsici, PWB-24, that has the highest level of known virulence (Oelke et al., 2003) was used for the screening. The inoculum preparation followed that of Bosland and Lindsey (1991), and modified by Oelke et al. (2003).

Foliar InOCUlation. The inoculation method to screen for phytophthora foliar blight was originally developed by Alcantara and Bosland (1994). The seedlings were inoculated by placing $45 \mu \mathrm{L}$ of inoculum on the leaves (40,000 zoospores $/ \mathrm{mL}$ ).

Stem inoculation. A nonwounding technique was used to test for stem blight resistance (Sy, 2003). To summarize the technique, a sterilized absorbent yarn (100\% pure cotton, $2.5 \mathrm{~mm}$ in diameter) was gently tied around the stem and the ends trimmed. A second piece of yarn was tied 3 to $4 \mathrm{~cm}$ below the top yarn to act as an absorbent buffer to avoid root contamination (Fig. 1). Yarns were soaked with distilled water $1 \mathrm{~h}$ prior to inoculation, to increase the adhesion of the inoculum to the yarn. The zoospore concentration was 50,000 zoospores $/ \mathrm{ml}$ in order to counter any effect of dilution from the prewetting of the yarn. A total volume of $45 \mu \mathrm{L}$ was placed on the upper yarn.

Root INOCULaTion. Bosland and Lindsey's (1991) method was used to screen for phytophthora root rot. Plant trays with drainage holes are placed into trays filled with water. Each plant cell received $5 \mathrm{~mL}$ of inoculum (2000 zoospores $/ \mathrm{mL}$ ). The flooded root zone condition is maintained for $\approx 48 \mathrm{~h}$ before the plant trays are removed and placed on a greenhouse bench.

\section{Experimental protocol}

Foliar VS. STEM. After allowing the original plants, and the cuttings to regrow ( $\approx 6-7$ weeks), the original plants were utilized to test for phytophthora stem blight, whereas the cuttings were tested for phytophthora foliar blight. Each plant was labeled to have its own identification number. The experiment was repeated twice with 167,73 , and $83 \mathrm{~F}_{2}$ plants. The testcross population was screened once with 39 plants.

Rоoт vs. STEM. The original plants were tested for phytophthora root rot and the cuttings served to test for phytophthora stem blight. The experiment was also repeated twice with 92, 91 , and $79 \mathrm{~F}_{2}$ plants tested. The testcross population of 48 plants was screened once.

After inoculation, all plants were placed in a mist chamber with a relative humidity of $80 \%$ and an air temperature of $28^{\circ} \mathrm{C}$.

Scoring. When the susceptible control showed disease symptoms of phytophthora root rot, stem blight, and foliar blight, all plants were scored. Plants that did not display any lesions on the roots, the stem, or on the leaves were considered resistant. On the other hand, plants with lesions on the roots, stem, or on the leaves were considered susceptible.

Statistical analysis. The segregation ratios were recorded in the $\mathrm{F}_{2}$ and in the testcross populations. A chi-square goodness-of-fit test with a 5\% significance level was used for the statistical analysis (SAS Inst., 1999). A test of homogeneity was also performed to ensure that the data could be combined over three experiments.

\section{Foliar blight vs. stem blight}

Phytophthora foliar blight. In all experiments, the susceptible control, 'Early Jalapeño' showed foliar blight symptoms, while the resistant control, 'Criollo de Morelos 334,' did not display any disease symptoms. The segregation in the $\mathrm{F}_{2}$ and in the testcross population respectively fit a 3:1 (resistant: susceptible), and a 1:1 (resistant : susceptible) ratio (Table 1).

Phytophthora Stem blight. The susceptible control, 'Early Jalapeno' consistently showed stem blight symptoms. The resistant control, 'Criollo de Morelos 334', did not display any disease symptoms. The segregation in the $\mathrm{F}_{2}$ and in the testcross population population respectively fit a 3:1 (resistant: susceptible), and a 1:1 (resistant: susceptible) ratio (Table 2).

Phytophthora Foliar blight/Phytophthora Stem blight. A total of $323 \mathrm{~F}_{2}$ plants were screened and the segregation fit a ratio of 9:3:3:1 (foliar resistant/stem resistant: foliar resistant/stem susceptible: foliar susceptible/stem resistant: foliar susceptible/ stem susceptible) (Table 3 ). In addition, the segregation in the testcross population fit a 1:1:1:1 (foliar resistant/stem resistant : foliar resistant/stem susceptible : foliar susceptible/stem resistant : foliar susceptible/stem susceptible) ratio (Table 3).

\section{Root rot vs. stem blight}

Phytophthora root rot. The susceptible control, 'Early Jalapeno' manifested symptoms of phytophthora root rot in all experiments. In addition, the resistant control, 'Criollo de Morelos 334', exhibited complete resistance. The segregation in the $\mathrm{F}_{2}$ population fit a 3:1 (resistant : susceptible) ratio, and the segregation in the testcross population fit a 1:1 (resistant : susceptible) ratio (Table 4).

Phytophthora Stem blight. All plants from the susceptible control, 'Early Jalapeno' had symptoms of phytophthora stem blight, whereas the resistant control, 'Criollo de Morelos 334' did not display any symptoms. The segregation in the $\mathrm{F}_{2}$ and in the testcross population respectively fit a 3:1 (resistant: susceptible), and a 1:1 (resistant: susceptible) ratio (Table 5). 
Table 1. Segregation ratios for resistance to phytophthora foliar blight in 'Criollo de Morelos 334', 'Early Jalapeño', $\mathrm{F}_{2}$, and testcross populations of Capsicum annuum.

\begin{tabular}{lcccc}
\hline Population & $\begin{array}{c}\text { Resistant (R) } \\
\text { plants (no.) }\end{array}$ & $\begin{array}{c}\text { Susceptible (S) } \\
\text { plants (no.) }\end{array}$ & $\begin{array}{c}\text { Expected } \\
\text { rations (R:S) }\end{array}$ & $P$ \\
\hline Criollo de Morelos 334 & 251 & 0 & NAy & NA \\
$\begin{array}{l}\text { Early Jalapeño } \\
\mathrm{F}_{2} \text { (Early Jalapeño } \times\end{array}$ & 2 & 225 & $\mathrm{NA}$ & NA \\
$\quad \begin{array}{l}\text { Criollo de Morelos 334) } \\
\text { Backcross }\end{array}$ & 231 & 92 & $3: 1$ & 0.1483 \\
$\quad$ Early Jalapeño $\left.\times \mathrm{F}_{1}\right)$ & 22 & 17 & $1: 1$ & 0.4233
\end{tabular}

${ }^{2}$ Number of resistant plants $(\mathrm{R})=$ plants with no disease symptoms, number of susceptible plants $(\mathrm{S})=$ plants with disease symptoms.

yNot applicable due to an expected value of zero.

Table 2. Segregation ratios for resistance to phytophthora stem blight in 'Criollo de Morelos 334,' 'Early Jalapeño,' $\mathrm{F}_{2}$, and testcross populations of Capsicum annuит.

\begin{tabular}{lcccc}
\hline Population & $\begin{array}{c}\text { Resistant (R) } \\
\text { plants (no.) }\end{array}$ & $\begin{array}{c}\text { Susceptible (S) } \\
\text { plants (no.) }\end{array}$ & $\begin{array}{c}\text { Expected } \\
\text { rations (R:S)z }\end{array}$ & $P$ \\
\hline Criollo de Morelos 334 & 251 & 0 & NAy & NA \\
$\begin{array}{l}\text { Early Jalapeño } \\
\mathrm{F}_{2} \text { (Early Jalapeño } \times\end{array} \quad 225$ & NA & NA \\
$\quad \begin{array}{l}\text { Criollo de Morelos 334) } \\
\quad \text { Backcross }\end{array}$ & 244 & 79 & $3: 1$ & 0.8221 \\
$\quad$ Early Jalapeño $\left.\times \mathrm{F}_{1}\right)$ & 21 & 18 & $1: 1$ & 0.6310 \\
\hline
\end{tabular}

${ }^{2}$ Number of resistant plants $(\mathrm{R})=$ plants with no disease symptoms, number of susceptible plants $(\mathrm{S})=$ plants with disease symptoms.

yNot applicable due to an expected value of zero.

Phytophthora RoOT Rot/PHYTOPHTHORA STEM BLIGHT. When the root rot was compared to stem blight, the segregation in the $\mathrm{F}_{2}$ population fit a 9:3:3:1 (root resistant/stem resistant : root resistant/stem susceptible : root susceptible/stem resistant : root susceptible/stem susceptible) ratio (Table 6). In addition, the segregation in the testcrosspopulation fit a 1:1:1:1 (root resistant/stem resistant : root resistant/stem susceptible : root susceptible/stem resistant : root susceptible/stem susceptible) ratio (Table 6).

\section{Discussion}

From this study, phytophthora root rot, stem blight, and foliar blight must be considered three different disease syndromes, each requiring a single and different gene for the expression of its resistance.

The segregating $\mathrm{F}_{2}$ population in the phytophthora foliar blight test fit the 3:1 ratio (Table 1). In addition, the segregation in the testcross population fit the $1: 1$ ratio (Table 1 ). These two ratios indicate that one dominant gene controls phytophthora foliar blight resistance. This confirms the conclusion reached by Walker and Bosland (1999).

Table 3. Segregation ratios for resistance to phytophthora foliar and stem blight in $\mathrm{F}_{2}$ and testcross populations of Capsicum annuum.

\begin{tabular}{|c|c|c|c|c|c|c|}
\hline Population & $\begin{array}{l}\mathrm{R} / \mathrm{R} \text { plants }{ }^{\mathrm{z}} \\
\text { (no.) }\end{array}$ & $\begin{array}{l}\mathrm{R} / \mathrm{S} \text { plants } \\
\text { (no.) }\end{array}$ & $\begin{array}{c}\text { S/R plants } \\
\text { (no.) }\end{array}$ & $\begin{array}{c}\text { S/S plants } \\
\text { (no.) }\end{array}$ & $\begin{array}{c}\text { Expected } \\
\text { ratios }(\mathrm{R}: \mathrm{S})^{\mathrm{z}}\end{array}$ & $P$ \\
\hline$\overline{\mathrm{F}_{2} \text { (Early Jalapeño } \times}$ & & & & & & \\
\hline Criollo de Morelos 334) & 179 & 52 & 65 & 27 & $9: 3: 3: 1$ & 0.2753 \\
\hline Backcross & & & & & & \\
\hline$\left(\right.$ Early Jalapeño $\left.\times \mathrm{F}_{1}\right)$ & 14 & 8 & 9 & 8 & $1: 1: 1: 1$ & 0.4684 \\
\hline
\end{tabular}

${ }^{2}$ Resistant plants $(\mathrm{R})=$ plants with no disease symptoms; susceptible plants $(\mathrm{S})=$ plants with disease symptoms. $\mathrm{R} / \mathrm{R}=$ foliar resistant/stem resistant; $\mathrm{R} / \mathrm{S}=$ foliar resistant/stem susceptible; $\mathrm{S} / \mathrm{R}=$ foliar susceptible/stem resistant; $\mathrm{S} / \mathrm{S}=$ foliar susceptible/stem susceptible
The $\mathrm{F}_{2}$ segregating population used to test phytophthora root rot resistance fit a 3:1 ratio and the segregating testcross population fit a 1:1 ratio (Table 4$)$. These ratios also indicate that one dominant gene controls phytophthora root rot resistance. These results also agree with previous finding by Walker and Bosland (1999).

When phytophthora stem blight was examined, the segregating $\mathrm{F}_{2}$ population fit a 3:1 while the testcross population fit a 1:1 ratio (Tables 2 and 5). This is also indicative of one dominant gene controlling resistance. This is the first report on the inheritance of this disease syndrome.

To determine whether the same or different genes control phytophthora stem blight and foliar blight resistance, data from both tests were combined. The $\mathrm{F}_{2}$ population fit a 9R/R:3R/S:3S/R:1S/S ratio (Table 3). In addition, the testcross population fit a $1 \mathrm{R} / \mathrm{R}: 1 \mathrm{R} /$ $\mathrm{S}: 1 \mathrm{~S} / \mathrm{R}: 1 \mathrm{~S} / \mathrm{S}$ ratio (Table 3 ). These two ratios are consistent for two independent, different genes controlling the resistant phenotype: one gene for phytophthora foliar blight and one gene for phytophthora stem blight.

After phytophthora stem blight was compared to foliar blight, it was then compared to root rot. The $\mathrm{F}_{2}$ population fit a $9 \mathrm{R} / \mathrm{R}: 3 \mathrm{R} / \mathrm{S}: 3 \mathrm{~S} / \mathrm{R}: 1 \mathrm{~S} / \mathrm{S}$ ratio (Table $6)$. In addition, the testcross population fit a $1 \mathrm{R} / \mathrm{R}: 1 \mathrm{R} / \mathrm{S}: 1 \mathrm{~S} / \mathrm{R}: 1 \mathrm{~S} / \mathrm{S}$ ratio (Table 6). Such ratios are consistent when two independent, different genes control the resistance: one for phytophthora root rot and one for phytophthora stem blight.

The conclusion reached in the comparative foliar/stem and root/stem studies confirm the conclusion reached in the single inoculation studies (root, stem, and foliar experiments), that is: a one-gene model for each system. In addition, at the infection level, $P$. capsici has a differential action according to the organs infected. Irwin et al. (1997) reported that chile plants affected by root rot lack conspicuous appressoria, whereas in the case of foliar blight, the pathogen produces pronounced appressoria. With a differential mode of infection, different pathways or signal cascades must exist for host response. This supports the evidence that separate genes are involved, or at least are regulated differently. An example of multiple disease syndrome is also reported in potato (Solanum tuberosum L.) where plants displaying tuber resistance to Phytophthora infestans [(Mont). de Bary] were vine and foliage susceptible and vice versa (Bonde et al., 1940; Rudorf et al., 1950). Similarly, a differential mode of infection for the tuber and the foliage has been reported for this system: haustoria encasement is noticeable in the tubers, whereas it is absent in the foliage (Hohl and Stossel, 1976).

Although three genes are needed for complete resistance, we can hypothesize that the gene-for-gene system (Flor, 1971) must be functioning in each system (root, stem, and 
Table 4. Segregation ratios for resistance to phytophthora root rot in 'Criollo de Morelos 334', ‘Early Jalapeño', $\mathrm{F}_{2}$, and testcross populations of Capsicum annuum.

\begin{tabular}{lcccc}
\hline Population & $\begin{array}{c}\text { Resistant (R) } \\
\text { plants (no.) }\end{array}$ & $\begin{array}{c}\text { Susceptible (S) } \\
\text { plants (no.) }\end{array}$ & $\begin{array}{c}\text { Expected } \\
\text { rations (R:S) }\end{array}$ & $P$ \\
\hline Criollo de Morelos 334 & 275 & 0 & NAy & NA \\
Early Jalapeño & 2 & 253 & NA & NA \\
$\mathrm{F}_{2}$ (Early Jalapeño $\times$ & & & & \\
$\quad$ Criollo de Morelos 334) & 208 & 54 & $3: 1$ & 0.1008 \\
BC $_{1}$ (Early Jalapeño $\times \mathrm{F}_{1}$ ) & 25 & 22 & $1: 1$ & 0.6617 \\
\hline
\end{tabular}

${ }_{\mathrm{z}}$ Number of resistant plants $(\mathrm{R})=$ plants with no disease symptoms, number of susceptible plants $(\mathrm{S})=$ plants with disease symptoms

yNot applicable due to an expected value of zero.

Table 5. Segregation ratios for resistance to phytophthora stem blight in 'Criollo de Morelos 334,' 'Early Jalapeño', $\mathrm{F}_{2}$, and testcross populations of Capsicum annuum.

\begin{tabular}{lcccc}
\hline Population & $\begin{array}{c}\text { Resistant (R) } \\
\text { plants (no.) }\end{array}$ & $\begin{array}{c}\text { Susceptible (S) } \\
\text { plants (no.) }\end{array}$ & $\begin{array}{c}\text { Expected } \\
\text { rations (R:S) }\end{array}$ & $P$ \\
\hline Criollo de Morelos 334 & 275 & 0 & NAy & NA \\
Early Jalapeño & 2 & 253 & NA & NA \\
$\mathrm{F}_{2}$ (Early Jalapeño $\times$ & & & & \\
$\quad$ Criollo de Morelos 334) & 197 & 65 & $3: 1$ & 0.9431 \\
BC $_{1}$ (Early Jalapeño $\times \mathrm{F}_{1}$ ) & 22 & 25 & $1: 1$ & 0.6617
\end{tabular}

${ }^{2}$ Number of resistant plants $(\mathrm{R})=$ plants with no disease symptoms, number of susceptible plants $(\mathrm{S})=$ plants with disease symptoms.

yNot applicable due to an expected value of zero. of New Mexican-type peppers. Phytopathology 83:607-611.

Bonde, R., F.J. Stevenson, and C.F. Clark. 1940. Resistance of certain potato varieties and seedling progenies to late blight in the tubers. Phytopathology 30:733-748.

Bosland, P.W. and D.L. Lindsey. 1991. A seedling screen for phytophthora root rot of pepper, Capsicum annuum. Plant Dis. 75:1048-1050.

Brett, M.T. 2002. Molecular basis of recognition between phytophthora pathogens and their hosts. Annu. Rev. Phytopathol. 40:137-167.

Flor,H.H. 1971. Current status of the gene-for-gene concept. Ann. Rev. Phytopathol. 9:275-296.

Hohl, H.R. and P. Stossel. 1976. Host-parasite interfaces in a resistant and a susceptible cultivar of Solanum tuberosum inoculated with Phytophthora infestans: Tuber tissue. Can. J. Bot. 54:900-912. Irwin, J.A., A.R. Crawford, and A. Drenth. 1997. The origins of phytophthora species attacking legumes in Australia. Adv. Bot. Res. 24:431-456. Oelke, L.M., P.W. Bosland, and R. Steiner. 2003. Differentiation of race specific resistance to phytophthora root rot and foliar blight in Capsicum annuum. J. Amer. Soc. Hort. Sci. 128:213-218.

Ortega, R.G., C.P. Espanol, and J.C. Zueco. 1991. Genetics of resistance to Phytophthora capsici in the pepper line 'SCM-334'. Plant Breeding

Table 6. Segregation ratios for resistance to phytophthora root rot and stem blight in $\mathrm{F}_{2}$ and testcross popula- 107:50-55. tions of Capsicum annuum.

\begin{tabular}{|c|c|c|c|c|c|c|}
\hline Population & $\begin{array}{c}\mathrm{R} / \mathrm{R} \text { plantsz } \\
\text { (no.) }\end{array}$ & $\begin{array}{c}\mathrm{R} / \mathrm{S} \text { plants } \\
\text { (no.) }\end{array}$ & $\begin{array}{c}\begin{array}{l}\text { S/R plants } \\
\text { (no.) }\end{array} \\
\end{array}$ & $\begin{array}{c}\begin{array}{c}\text { S/S plants } \\
\text { (no.) }\end{array} \\
\end{array}$ & $\begin{array}{c}\text { Expected } \\
\text { ratios }(\mathrm{R}: \mathrm{S})^{\mathrm{z}}\end{array}$ & $P$ \\
\hline \multicolumn{7}{|l|}{$\overline{F_{2}}$ (Early Jalapeño $\times$} \\
\hline Criollo de Morelos 334) & 163 & 45 & 36 & 18 & 9:3:3:1 & 0.1288 \\
\hline $\mathrm{BC}_{1}\left(\right.$ Early Jalapeño $\left.\times \mathrm{F}_{1}\right)$ & 14 & 11 & 9 & 14 & $1: 1: 1: 1$ & 0.6823 \\
\hline
\end{tabular}

foliar). Avirulence genes have not been characterized yet in $P$. capsici, but they have been in Phytophthora sojae (Hildebrand) and in $P$. infestans, which along with $P$. capsici are oomycetes (May et al., 2002; Van der lee et al., 2001). The gene-for-gene theory stipulates that in race-specific interactions, the host plant is able to thwart infection by the rapid deployment of defense functions. This is made possible by the existence in the host of a dominant resistance gene that allows the plant to recognize a specific pathogen that possesses an avirulence gene.

\section{Literature Cited}

Alcantara, T.P. and P.W. Bosland. 1994. An inexpensive disease screening technique for foliar blight of chile pepper seedlings. HortScience 29:1182-1183.

Bartual, R., E.A. Carbonell, J.I. Marsal, J.C. Tello, and T. Campos. 1991. Gene action in the resistance of peppers (Capsicum annuum) to phytophthora stem blight (Phytophthora capsici L.). Euphytica 54:195-200.

Biles, C. L., M. M. Wall, M. Waugh, and H. Palmer. 1993. Relationship of phytophthora fruit rot to fruit maturation and cuticle thickness Park. 1989. Expression of agerelated resistance in pepper plants infected with Phytophthora capsici. Plant Dis. 73:745-747.

May, K.J., S.C. Whisson, R.S. Zwart, I.R. Searle, J.A.G. Irwin, D.J. Maclean, B.J. Carroll, and A. Drenth. 2002. Inheritance and mapping of eleven avirulence genes in Phytophthora sojae. Fungal Genet. Biol. In press.

Reifschneider, F.J. B., L.S. Boiteux, P.T. Della Vechia, J.M. Poulos, and N. Kuroda. 1992. Inheritance of adult-plant resistance to Phytophthora capsici in pepper. Euphytica 62:45-49.

Rudorf, W., P. Schaper, H. Ross, M. Baerecke, and M. Torka. 1950. The breeding of resistant varieties of potatoes. The Amer. Potato J. 27:222-235.

SAS Institute. 1999. Version 8.00. SAS Inst., Cary, N.C.

Smith, P.G., K.A. Kimble, R.G. Grogan, and A.H. Millett. 1967. Inheritance of resistance in peppers to phytophthora root rot. Phytopathology $57: 377-379$

Sy, O. 2003. Development of a screening technique for phytophthora stem blight and a comparative study of the inheritance of phytophthora root rot, stem blight, and foliar blight resistance in Capsicum annuum. MS Thesis, New Mexico State Univ., Las Cruces.

Van der lee, T., A. Robold, A. Testa, J. W. Van't Klooster, and F. Govers. 2001. Mapping of avirulence genes in Phytophthora infestans with amplified fragment length polymorphism markers selected by bulked segregant analysis. Genetics 157:949-956

Walker, S.J. and P.W. Bosland. 1999. Inheritance of phytophthora root rot and foliar blight resistance in pepper. J. Amer. Soc. Hort. Sci. 124:14-18.
Kim, Y.J., B.K. Hwang, and K.W. 